\title{
KEMAHIRAN MENYIMAK DALAM PROSES PEMBELAJARAN BAHASA ARAB
}

\author{
Muh. Jabir \\ STAIN Datokarama Palu, Jl. Diponegoro 23 Palu \\ e-mail:muh.jabir@ymail.com
}

\begin{abstract}
Abstrak
Menurut para ahli linguistik, ada empat kemahiran yang sangat penting untuk dilalui dan dikuasai sebaik-baiknya oleh para peserta didik dalam usaha mempelajari berbagai macam bahasa, tak terkecuali bahasa Arab. Pertama kemahiran menyimak, kedua kemahiran berbicara, ketiga kemahiran membaca, dan keempat adalah kemahiran menulis. Dalam tulisan ini Penulis akan mengemukakan kemahiran yang pertama, yaitu kemahiran menyimak. Karena tanpa kemahiran menyimak yang baik, akan terjadi banyak kesalah pahaman dalam berkomunikasi antara sesama pemakai bahasa.

According to linguists, there are four skills of language which must be mastered by leaners learners in learning a language, Arabic is no exception. First listening skill, second speaking skill, third reading skill and fourth writing skill. In this article, the author will focus his discussion on the first skill, namely listening skill. The reason is that without good listening skill, there will be a lot of misunderstanding in communication among the language users.
\end{abstract}

Kata Kunci: Kemahiran, Menyimak, Pembelajaran, Bahasa Arab

\section{PENDAHULUAN}

Menyimak adalah mendengarkan secara langsung ucapan atau petunjuk dari pendidik tentang cara melafalkan kata-kata atau 
kalimat dengan fasih dan benar dan sekaligus mempelajari artinya. Manfaat dari kegiatan menyimak adalah untuk membiasakan para peserta didik mendengar dengan baik ujaran-ujaran bahasa Arab, disamping dapat menciptakan gairah dan motivasi belajar dalam diri peserta didik. Secara umum menyimak bertujuan untuk memberikan pemahaman kepada peserta didik mengenai ujaranujaran bahasa Arab, baik sebagai bahasa sehari-hari maupun sebagai bahasa resmi. Kemahiran menyimak dapat dicapai dengan latihan-latihan mendengarkan perbedaan-perbedaan bunyi unsur kata dengan unsur kata lainnya sesuai makhrajnya, baik langsung dari penutur aslinya maupun melalui rekaman dari tape, baik unsur kata yang terpisah dari pemahaman arti maupun bunyi kata dan kalimat dengan pemahaman arti yang terkandung.

\section{PROSES-PROSES KEMAHIRAN MENYIMAK}

Menurut Brown, sebagaimana dikutip Iskandarwassid dkk., bahwa dalam kemahiran menyimak terdapat delapan proses, yaitu:

- Pendengar memproses raw speech dan menyimpan image dalam short term memory. Image tersebut berisi antara lain frase, tanda-tanda baca, dan pola-pola tekanan kata dari pembicaraan yang ia dengar;

- Pendengar menentukan tipe dalam setiap peristiwa pembicaraan yang sedang diproses. Selanjutnya pendengar harus menentukan kembali bahwa apakah pembicaraan itu berbentuk suatu dialog, pidato, dan lain sebagainya, yang kemudian ia menginterpretasikan pesan yang ia terima;

- Pendengar mencari maksud dan tujuan pembicaraan dengan mempertimbangkan bentuk dan jenis pembicaraan, konteks, dan isi;

- Pendengar me-recall latar belakang informasi sesuai dengan konteks subjek masalah yang ada. Pengetahuan yang diperoleh pendengar akan digunakan dalam membentuk hubunganhubungan kognitif untuk memberikan interpretasi yang tepat terhadap pesan yang disampaikan;

- Pendengar mencari arti literal dari pesan yang ia dengar. Proses ini menuntut pendengar untuk memberikan interpretasi semantik. 
- Pendengar menentukan arti yang dimaksud;

- Pendengar mempertimbangkan, apakah informasi yang ia terima harus disimpan di dalam memorinya atau ditunda;

- Pendengar menghapus bentuk pesan-pesan yang ia telah terima (Iskandarwassid dkk., 2008: 227).

\section{TAHAP-TAHAP LATIHAN KEMAHIRAN MENYIMAK}

\section{Latihan Pengenalan}

Kemahiran menyimak pada tahap pertama bertujuan agar peserta didik dapat mengidentifikasi bunyi-bunyi bahasa Arab dengan benar. Latihan pengenalan ini sangat penting karena sistem tata bunyi bahasa Arab banyak yang berbeda dengan bahasa ibu peserta didik yang telah lama dikenal oleh mereka.

Satu keringanan bagi pengampu mata kuliah bahasa Arab bahwa pada umumnya peserta didik bangsa Indonesia, khususnya yang beagama Islam telah mengenal bunyi-bunyi bahasa Arab sejak masa kecilnya melalui pelajaran membaca Alquran dan bacaan-bacaan salat. Namun hal ini tidak mengurangi pentingnya latihan pengenalan. Latihan pengenalan dapat berupa latihan mendengar untuk membedakan bunyi huruf dengan cara mengontraskan pasangan-pasangan huruf yang hampir sama.

\section{Latihan Mendengarkan dan Menirukan}

Setelah peserta didik mengenal bunyi-bunyi bahasa Arab melalui ujaran-ujaran yang didengarnya, latihan berikutnya adalah mereka dilatih untuk mengucapkan dan memahami makna yang terkandung dalam ujaran tersebut. Dengan demikian latihan kemahiran menyimak sekaligus melatih dasar-dasar kemampuan reseptif dan produktif peserta didik.

Latihan berikutnya adalah latihan mendengarkan dan menirukan. Kegiatan pertama yang dilakukan oleh pendidik dalam latihan ini adalah memperkenalkan kepada peserta didik kata-kata atau pola kalimat yang baru. Latihan menirukan ini difokuskan pada bunyi-bunyi bahasa yang asing bagi peserta didik, pada pengucapan vokal panjang dan pendek, pada huruf yang bertasydid, dan yang tidak bertasydid.

\section{Latihan Mendengarkan dan Memahami}


Setelah peserta didik mengenal bunyi-bunyi bahasa dan dapat mengucapkannya, latihan berikutnya adalah memahami bentuk dan makna dari apa yang didengarnya. Latihan ini dapat dilakukan dengan berbagai macam teknik, antara lain:

\section{Latihan Melihat dan Mendengar (نظر واسع)}

Dalam tahap ini, pendidik memperdengarkan materi yang sudah direkam, dan pada waktu yang sama pendidik memperlihatkan rangkaian gambar yang mencerminkan arti dan isi materi yang didengar oleh peserta didik tadi.

\section{Latihan Membaca dan Mendengar (اقرا واسعع)}

Tahap berikutnya adalah pendidik memperdengarkan materi bacaan yang sudah direkam dan peserta didik membacakan teks dengan mengikuti materi yang diperdengarkan. Pada tingkat permulaan, perbendaharaan kata-kata yang diketahui oleh peserta didik masih sangat terbatas, Oleh karena itu harus dipilihkan bahan yang sederhana dan tidak terlalu panjang.

\section{Latihan Mendengarkan dan Memeragakan (قرا ومثل)}

Dalam latihan ini, peserta didik diminta untuk melakukan gerakan non verbal sebagai jawaban terhadap stimulus yang diperdengarkan oleh pendidik. Kegiatan ini tidak terbatas pada ungkapan sehari-hari yang sering digunakan oleh pendidik di dalam kelas, tetapi juga pada kegiatan-kegiatan yang berlaku di luar kelas yang dapat didemonstrasikan (Effendy, 2005: 103).

\section{BAHAN TES KEMAHIRAN MENYIMAK}

Menurut Nurgiyantoro sebagaiman dikutip oleh M. Ainin, dkk., bahwa yang perlu diperhatikan dalam menyusun bahan tes kemahiran menyimak, adalah:

- Memperhatikan tingkat Kesulitan Wacana

- Memperhatikan isi dan cakupan wacana yang sesuai dengan tingkat perkembangan psikologi peserta didik, termasuk di dalamnya minat dan kebutuhan peserta didik;

- Memperhatikan jenis-jenis wacana. Selain itu, hendaknya wacana yang diperdengarkan kepada peserta didik sebagai tes kemahiran menyimak adalah wacana simak dari suara penutur 
asli. Karena dengan cara seperti ini, peserta didik dibiasakan mengenal tuturan dari penutur asli, sehingga apa bila mereka berinteraksi dengan penutur asli, tidak asing lagi bagi mereka, baik dari sisi kecepatan, intonasi maupun uslubnya (Ainin, 2006: 135).

\section{KOMPETENSI YANG DIUKUR DALAM TES KEMAHIRAN MENYIMAK}

Tes berasal dari bahasa latin testum yang berarti alat untuk mengukur tanah. Sedangkan dalam bahasa Prancis Kuno, tes berarti ukuran yang dipergunakan untuk membedakan antara emas dengan perak serta logam lainnya. Dalam bahasa Inggris ditulis dengan test. Dalam bahasa Indonesia diterjemahkan dengan tes, ujian atau percobaan. Dan dalam bahasa Arab diterjemahkan dengan imtihan.

Sementara pengertian tes menurut istilah, sebagaimana dijelaskan oleh F. L. Goodenough yang dikutip oleh Anas Sudijono, tes adalah suatu tugas yang diberikan kepada peserta tes dengan maksud membandingkan kecakapan mereka antara yang satu dengan yang lainnya (Sudijono, 2003: 66).

Hal yang senada tentang pengertian tes dari segi istilah adalah menurut Sumadi Suryabrata yang dikutip oleh M. Chabib Thoha, bahwa tes adalah pertanyaan-pertanyaan yang harus dijawab dan atau perintah-perintah yang harus dijalankan oleh peserta didik, yang kemudian pendidik memberikan nilai dengan cara membandingkan dengan standar atau dengan peserta didik lainnya (Thoha, 2001: 43).

Ada beberapa istilah yang berkaitan dengan tes dan masingmasing mempunyai pengertian yang berbeda, yaitu test, testing, tester, dan testee. Test adalah alat atau prosedur yang dipergunakan untuk mengadakan pengukuran dan penilaian. Testing adalah saat berlangsungnya pengukuran dan penilaian. Tester adalah orang yang melaksanakan tes, atau pembuat tes, atau orang yang sed. ang melakukan eksperimen. Testee adalah peserta tes atau peserta ujian (Sudijono, 2003: 66).

Berdasarkan pengertian di atas dapat dipahami bahwa tes adalah tugas-tugas yang harus dikerjakan oleh peserta didik, yang dengan pekerjaan itu pendidik memberikan nilai kepada peserta didik sesuai dengan ketentuan penilaian. 
Kemahiran menyimak merupakan salah satu kemahiran yang sangat penting dalam proses pembelajaran bahasa, karena ia merupakan salah satu bentuk kegiatan dalam berkomunikasi. Berdasarkan hal tersebut, indikator kompetensi yang diukur dalam tes kemahiran menyimak bahasa Arab adalah:

- Kemampuan mengidentifikasi bunyi huruf;

- Kemampuan membedakan bunyi huruf yang mirip;

- Kemampuan memahami arti kosa kata dan frasa;

- Kemampuan memahami kalimat;

- Kemampuan memahami wacana:

- Kemapuan memberikan tanggapan dari isi wacana yang didengarnya (Ainin, 2006: 135).

\section{PENUTUP}

Bahasa, tak terkecuali bahasa Arab memegang peranan penting dalam kehidupan manusia. Dengan bahasa seseorang dapat menyampaikan ide, pikiran, dan informasi kepada orang lain baik secara lisan maupun tulisan. Dengan demikian bahasa berfungsi sebagai alat komunikasi dan interaksi. Oleh karena itu, maka pembelajaran bahasa hendaknya dimulai dengan mengajarkan kemahiran menyimak sebelum mengajarkan kemahiran membaca dan menulis.

\section{DAFTAR PUSTAKA}

Ainin, M. dkk., 2006. Evaluasi dalam Pemebelajaran Bahasa Arab. Cet; I: Malang: Misykat.

Bawani, Imam. 1987. Tata Bahasa: Bahasa Arab I. Surabaya: AlIkhlas.

Effendy, Ahmad Fuad. 2005. Metodologi Pengajaran Bahasa Arab. Cet. III; Malang: Misykat.

Iskandarwassid dkk., 2008. Strategi Pembelajran Bahasa. Cet. I; Bandung: PT Remaja Rosdakarya.

Jabir, Muh., 2010. Sistem Pembelajaran Bahasa Arab. Cet. I; Palu: Sulteng Center Press.

Sudijono, Anas. 2003. Pengantar Evaluasi Pendidikan. Cet. IV; Jakarta: PT RajaGrafindo Persada. 
Tarigan, Henry Guntur. 1985. Menyimak sebagai Suatu Keterampilan Berbahasa. Cet. X; Bandung: Angkasa.

Thoha, M. Chabib. 2001. Teknik Evaluasi Pendidikan. Cet. IV; Jakarta: PT RajaGrafindo Persada. 